Combined Effects of Franchise Management Strategies and Employee Service Performance on Customer Loyalty - A Multi-Level Perspective

\author{
B. Ramaseshan \\ School of Marketing, Curtin University \\ Email: Ram.Ramaseshan@cbs.curtin.edu.au
}

Fazlul K. Rabbanee

School of Marketing, Curtin University

Email: f.rabbanee@curitn.edu.au

Oksana Burford

School of Pharmacy, Curtin University

Email: O.Burford@curtin.edu.au 


\title{
Combined Effects of Franchise Management Strategies and Employee Service Performance on Customer Loyalty - A Multi-Level Perspective
}

\begin{abstract}
This study examines the combined effects of three franchisor management strategies namely innovative culture, support services and autonomy on service performance of the franchisee store employees and the loyalty of their customers. Data were collected from a total of 38 employees and 679 customers of 25 franchisee stores. The study employs multilevel analysis on a nested dataset created by matching customer data with employee data for each store. The results reveal that customer loyalty of a franchisee store is positively influenced by the service performance of its employees and the support services received by the employees of the store from its franchisor. On the other hand, it has been found that franchisor management strategy such as innovative culture and autonomy negatively influence customer loyalty of the franchisee store. The paper discusses relevant theoretical and managerial implications of the findings.
\end{abstract}

Key words: Franchise business, employee service performance, innovative culture, support services, autonomy, customer loyalty

\section{Introduction}

Franchising has received considerable academic attention in small business, management and entrepreneurship literature (Combs et al., 2011; Dant et al., 2011; Dada et al., 2012). The predominant theme of franchising in these literatures is to serve as a vehicle for successful growth and expansion of nationwide retail chains and as a way for individuals to establish their own businesses. Despite the popularity of the franchising business model across the sectors and across the world, selection of qualified franchisees has been one of the most pervasive problems at the operational level (Saraogi, 2009). Consequently, franchisors' ability to attract partners to work together has received considerable interest from the researchers (e.g. Dant \& Kaufmann, 2003; Lafontaine \& Kaufmann, 1994; Shane, Shankar \& Aravindakshan, 2006). Yet, partnering and 
sustaining good relationships between franchisor and franchisee is one of the central challenges facing franchisors (Blut et al., 2011). The value of partnering between franchisor and franchisee has led to a wealth of research focusing on strategies that franchisor firms adopt to attract franchisees to work with them (e.g. Eisenhardt \& Schoonhoven, 1996; Powell et al., 1996). However, little is known about whether and how franchisors' strategies affect franchisees' performance, especially the performance of franchisee employees. Although franchisee employee performance is likely to be influenced by franchisors' management strategies and is found to positively influence consumers' attitudes and behaviour (Rabbanee, Burford \& Ramaseshan 2015); no research thus far examined the chain of effects of : franchisor management strategies - franchisee employee performance - consumer loyalty.

Franchisees may adopt various behavioural responses to franchisor-initiated strategies. Some acts are constructive in nature. For example, some franchisees may accept and advocate the strategy adopted by the franchisor; others may pursue destructive responses, such as neglecting, or avoiding the strategy suggested by the franchisor and may fight against the changes, or even leaving the franchise system (Croonen \& Brand, 2015). This is harmful for the franchise system in terms of its efficiency and effectiveness as well as in terms of ensuring ultimate customers' loyalty. However, there is a lack of understanding in the existing literature on how franchisees' responses to franchisors' strategies affect ultimate consumers' attitude and behaviour. Specifically, the franchise literature is silent about the effects of franchisor strategies on franchisee employee performance which in turn influence customer loyalty.

Employee service performance is the behaviour and response of the employees while serving and helping customers (Liao \& Chuang, 2004). Although providing customer centric service together with sound franchisor strategies are very important in enhancing customer loyalty in pharmacy context, research on the customer/patient perspective in the pharmacy services is sparse (White \& Klinner, 2012; McMillan et al., 2014). 
In this backdrop, the key purpose of this study is to examine the combined effects of franchisor management strategies and franchisee employee performance on consumer loyalty. Since the nature and effectiveness of the franchise management strategies have effect on franchisee employees; and that employee service performance has an effect on customer loyalty; we model the effects of the franchise management strategies and employee service performance on customer loyalty from multilevel view using hierarchical linear modelling (HLM) and using real time multilevel company data collected from both franchisee employees and consumers. Next we discuss the extant literature, hypotheses, method, and results, followed by discussion and implications of the findings.

\section{Literature and Hypotheses}

Franchising constitutes the fastest growing retail format in history (White, 2010). It is an increasingly important type of inter-firm relationships in which a franchisee pays for the right to use a franchisor's business format in running its business and agrees to conform to franchisor's standards (Davies et al., 2011; Spinelly \& Birley, 1996). Franchise organizations primarily compete through operation of a large number of very similar outlets based on a uniform business model (Szulanski \& Jensen, 2008). Guided by an agency-theoretic perspective, franchising represents an efficient method for firms to acquire capital necessary to achieve economies of scale associated with large-scale operations, while minimizing monitoring costs through an improvement in the alignment of principal and agent incentive structures (Castrogiovanni et al., 2006). Franchisees, as independent owners, are more likely to maintain uniform standards, adopt needed adaptations and local market initiatives that support the franchise system (Norton, 1988; Dant et al., 2013). Although the franchisor-franchisee relationship is usually governed by formal contracts, such contracts often cannot specify all possible contingencies, especially in the context of international franchisees, where the franchisees feel the need to adapt local practices. Irrespective of the nature of the relationship and geographical location of the franchisor and franchisee, employee performance at 
franchisee level is an essential precursor of customer loyalty towards the franchisee store, including the community pharmacy store (Rabbanee et al., 2015).

Community pharmacy in Australia includes about 5,000 stores (Hamilton, 2009), which are primarily operated on a franchisor-franchisee relationship basis. Pharmacies provide both commercial and health care services (Jacobs et al., 2011). Employees of these community pharmacies play a far more significant and distinct role compared to the employees in traditional retail contexts. In addition to dispensing medicines, pharmacists perform a range of other tasks such as communicating with doctors, supervising the sale of scheduled medicines, consulting consumers with a wide range of health problems, and administering pharmacotherapy programs; thereby contributing to improving or maintaining patients' quality of life (Bush et al., 2009). Community pharmacies must ensure the availability of a registered pharmacist at all times during their operating hours; and the pharmacist must spend time with the patient to explain ingredients, packaging differences, relevant compliances, and also maintain ongoing vigilance to avoid medicine error (Beecroft, 2007). Pharmacy consumers also place a high value on close patient-pharmacist relationships and demand availability of the pharmacist for advice including health related issues, drug ingredients, differing brand names and drug names (Xu, 2002; Larson, 1998). Also, the three parties (doctor, pharmacist and patient) involved in the medicine supply process may use different names for the medicine, which is confusing and potential source of errors. All these factors affect health outcomes (Beecroft, 2007), lay impetus for rendering a compliant, high quality, error free service by the pharmacy employees. That is why community pharmacies are usually operated following uniform business procedure under franchise format.

Community pharmacies are facing hyper-competition worldwide due to the entry of new competitors (Brooks et al., 2007). In Australia, the situation is critical due to the growing dominance of discount pharmacies in the market (Singleton \& Nissen, 2014) and to the role of supermarkets as an OTC (over the counter) medicine dispenser. Traditional community pharmacies are losing their market share as they do not have adequate economies of scale to compete with the price-based 
discount pharmacies. Consequently, Australian community pharmacies contend with rising costs and a downturn in net profits (Beecroft, 2007). Overheads, particularly pharmacist wages, have increased at double digit growth rates for the last 3 years due to the shortage of health professionals ${ }^{1}$. Furthermore, pharmacy consumers seek competitive pricing in health and beauty products and over the counter medicines, leading to a robust price competition between pharmacies (Beecroft, 2007). Focusing on just selling medicine by playing the role of medicine dispenser is not sustainable any more (Shuai et al., 2012). Further recent research argued that customers are likely to pay additional dollars to their community pharmacies if they receive personalized services from of the community pharmacies (Singleton, 2013).

In such a scenario, employees of community pharmacies can play a key role in differentiating the services offered by the pharmacy stores with the employee performance likely to be influenced by the franchisor management strategies. There is limited research on the role of franchise management strategies in employee performance and customer outcomes in Australian pharmacy services. We will now discuss the theoretical perspective of the employee service performance, customer loyalty and relevant franchise management strategies from a multilevel perspective.

\section{Employee Service Performance and Customer Loyalty - A Multilevel Perspective}

Employee performance (EP) is an essential part of customers' assessment of service quality and their relationship with the service provider (Bitner, 1990; Gwinner et al., 1998; Hennig-Thurau et al., 2006). Employee performance, in general, refers to behaviours that are under the control of individual employees and that are relevant to organizational goals (Campbell, McCloy, Oppler, \& Sager, 1993). Employees' service performance refers to their behaviours in serving and helping customers (Liao \& Chuang, 2004). In case of community pharmacies, the desired performance from the employees demands both functional and emotional dimensions, whereby employees render

\footnotetext{
${ }^{1}$ Annabel, B. (2006). Confronting the brutal facts. Australian Journal of Pharmacy, 87, 78-82.
} 
expert health consultation as well as expressing socially desirable emotions during service transactions that follow some display rules mandated by the organization (Ashforth \& Humphrey, 1993). Pharmacy employees are expected to express positivity and behave in such a way that demonstrates reliability and provide a sense of personal care (Hochschild, 1983). However, while the employees of a store perform their work, they share some given contextual factors that determine the quality of their service performance (Liao \& Chuang, 2004).

Employees' service performance at franchisee level may depend on the franchisor management strategies. Previous research focused on different strategies such as effective communication (Chung et al., 2006; Doherty \& Alexander, 2004), dealing with franchisees' opportunism (Gaseenheimer et al., 1996), obtaining franchisees' satisfaction and trust (Chiou et al., 2004) as the pre-cursor for successful franchisee relationships and performance. Gallini and Lutz (1992) focused on specific strategies that franchisors could adopt to attract franchisees and expand business. One of the key challenges that franchisors continually encounter is how best to retain control over their franchisees without having any conflict with the franchisees and dampening their performance. Franchisors' success in part depends on their ability to manage the friction, manage franchisees' desire for more sovereignty (Strutton, Pelton \& Lumpkin, 1993) and make them committed towards the franchise relationship. Unfortunately, research focusing on how to obtain franchisees' efforts towards the franchise relationship is inadequate, although DiPietro et al. (2008) showed, through an exploratory study, that franchisees' are less aggressive in management style and possess significantly lower level of organizational commitment. Bordonaba-Juste and PoloRedondo (2008) examined the role of interdependence and relational norms as the key antecedents of franchisees' commitment towards the franchise relationship. However, no existing research examined the role of franchisors' management strategies on franchisee employee service performance.

We focussed on the quality of employee service performance in community pharmacies. Unlike in other service organizations, pharmacists often work as frontline employees and their role 
is very critical and delicate due to the nature of their job and customer demand. Hence their performance quality is a major issue to the customer in terms of their trust and loyalty. In addition, loyalty of the pharmacy customer depends not only on perceived value received from the products purchased from the pharmacy store, but also on the performance of the franchisee employees' performance (Rabbanee et al., 2015). The behaviour of the employee plays an important role in shaping the customer's perception of service quality (Liao \& Chuang, 2004). Hence, it is justified to pursue an in-depth study on how customer loyalty in community pharmacies is influenced by the employee performances of franchisee stores and the respective franchisor firm's management strategy.

We developed our theoretical framework based on the multi-level view of the customer loyalty. Employee service performance, the customer level driver, perceived by the customers; whereas franchisor management strategies, the management level driver, is perceived by the franchisee employees of the community pharmacy stores. This requires modelling the variance of customer loyalty based on the variance of both employee performance (Level 1 - customer level driver of customer loyalty) and management strategies of the franchisor (Level 2 - management level driver of customer loyalty). We recognize that an organization is an integrated system and that individual and organizational factors interact and combine to shape individual and organizational outcomes (Kozlowski \& Klein, 2000). Consistent with this multilevel perspective, our expectation was that individual employees' service performance would be influenced by the franchisor management strategies and would contribute to generating customer loyalty (Liao \& Chuang, 2004). Next, we discuss relevant hypotheses for our conceptual framework.

\section{Customer level driver of customer loyalty (Level 1)}

Customer loyalty is the outcome variable in the proposed conceptual framework. It is the overall attachment or deep commitment of the buyer to a product, service, brand, or organization (Oliver, 1999). Firms usually spend a substantial amount of resources in establishing and nurturing relationships with customers in order to gain and increase customer loyalty. In franchise context, 
customers encounter franchisees and their employees more than the franchisor. Hence, employee service performance as perceived by the customers, is expected to be one of the key drivers of customer loyalty.

As mentioned earlier, employee service performance involves employee activities that bind an organization with its customers (Gronroos, 1990). Employee activities are aimed at maintaining customer loyalty by fulfilling the promises made to the customer (Berry, 1995). These activities are a critical factor in developing effective working relationships with customers (Gwinner et al., 1998). Customer opinion about employee service performance is an important factor in seeking to define how the employees perform; because customer perception of the service quality of a firm largely depends on employee activities and behaviour. Thus customer expectation is the key basis of employee performance standards in a service setting, encouraging employees to engage in behaviours that are particularly effective in achieving desirable customer outcomes (Bowen \& Waldman, 1999; Liao \& Chuang, 2004). We emphasize the quality of employee performance in community pharmacies in terms of how empathic and dependable they are towards the pharmacy customers. The role of the employees in a community pharmacy is very critical and delicate due to the nature of their work and customer expectations, hence their performance quality is a major issue of concern for the customer in terms of their loyalty. The desired performance quality of employees of a community pharmacy demands both functional and emotional dimensions, whereby employees render expert health consultation as well as expressing socially desirable emotions during service transactions in terms of rules mandated by the organization (Ashforth \& Humphrey, 1993; Rabbanee et al., 2015). Our position is also supported by past franchise literature (Evanschitzky et al., 2011) which states that franchisor-franchisee satisfaction positively influences customer satisfaction and this relationship is fully mediated by employee satisfaction. Therefore, we hypothesize that customer loyalty of the franchise community pharmacy stores is influenced by the franchisee employee service performance.

H1: Franchisee employee service performance positively influences customer loyalty. 


\section{Management Level Drivers of Customer Loyalty (Level 2)}

\section{Franchisors' management strategies}

Franchisors usually offer managerial assistance to the franchisees and in turn franchisees agree to run the business according to franchisors specifications. Franchisors often set strict guidelines for franchisees performance and expect franchisees to comply with the set guidelines (Strutton et al., 1995). Previous research emphasized effective coordination between franchisor and franchisee to obtain overall success of the franchising business (Chung et al., 2006; Doherty \& Alexander, 2004). White (2010) focused on the impact of the franchisor strategy creation style in the formation of a trustworthy climate in the franchise system. Bordonaba-Juste and Polo-Redondo (2008) found that interdependence and relational strategy influenced franchisee commitment. In addition, relationship marketing literature in $\mathrm{B} 2 \mathrm{~B}$ context highlighted the social relationship strategies that arise from the salespeople and their performance, as the most effective way to generate customer loyalty (Palmatier et al., 2006; Blut et al., 2011). However, existing literature is largely silent about the effects of franchisors' management strategies on franchisee employee performance en-route to customers' responses. This paper focuses on three franchisor management strategies: innovative culture, support services, autonomy, and their effects on employee (franchisee) service performance and eventually on customer loyalty. We have selected these three management strategies due to their high relevance in the franchise business context. Franchise channels are not only economic entities, they are also social systems characterized by the dual elements of conflict and cooperation (Etgar, 1979; Strutton et al., 1993). Franchisees generally need to sustain continuing relationships with their franchisors and are usually dependent on their decisions regarding how the fruits of channel membership will be distributed. Unlike other channels that feature largely autonomous memberships, power of the franchise business system is generally concentrated in the hands of the franchisor (Selz, 1992; Strutton et al., 1993). Such power can be exercised by the franchisor to forcefully suspend manifested conflict within the franchise system. The franchisor may promote innovativeness, autonomy and support to the franchisee as a ready means to inspire franchisee 
performance and/or resolve conflicts with the franchisee. However, it is still unknown whether these management strategies influence franchisee employee performance, which is the key purpose of this research. Next, we discuss literature relating to the constructs and draw hypotheses in this regard.

\section{Innovative culture}

Organizational culture refers to activities that occur naturally within the organization (Lundy \& Cowling, 1996; Uzkurt et al., 2013). The innovative culture of an organization emphasises the existence of an organizational environment that promotes innovative behaviour, creativity, and the willingness to take chances among its employees (Menon \& Varadrajan, 1992; Ramaseshan et al., 2013), and which thus develops new practice and knowledge (Dant \& Nasr, 1998). Innovation in marketing literature has been relatively product intensive (Han, Kim \& Srivastava, 1998) as marketing literature predominantly defined innovation from product-related breakthroughs. However, out of the numerous typologies of innovation, administrative innovation (Damanpour, 1991) is relevant in the case of franchise businesses due to the nature and structure of the business relationship between franchisor and franchisee. Administrative innovations focus on new or unique administrative processes and are directly related to the management of the organization, rather than the product or service of the organization (Damanpour \& Evan, 1984; Damanpour, 1991). Although a uniform business model is the key essence of any franchise business involving the operation of a large number of very similar outlets, organizations pursuing geographical growth need adapting transferred knowledge to fit varied local environments (Szulanski \& Jensen, 2008). Such local adaptation promotes innovation in managing the needs of the local customers. Following the uniform operating procedure may inhibit the performance of the local franchisees (Kaufmann \& Eroglu, 1999), especially if the franchisees are operating in overseas locations where local adaptation is indispensable for the successful expansion of the franchise business.

However, in case of the domestic franchise business where the franchisees are not located overseas, local pressure for innovative ways of doing things is less relevant. In such a case, innovation in the form of local adaptation may undermine the ability to utilize the given template or 
original set of practices (Jensen \& Szulanski, 2007). Although this may discourage innovation, copying the original templates as closely as possible may be found more effective than local innovation for a domestic franchise business. Szulanski and Jensen (2008) found empirical evidence relating to this and mentioned that there is a strong negative correlation between innovation and franchise network growth. This is further supported by the existing franchise literature (e.g. Dant \& Nasr, 1998; Weaven et al., 2014) which argued that the franchisors act as a central information and learning repository by adopting one-way communication strategies with franchisees, limit knowledge development through innovative actions, and thus, minimize risks associated with nonconformity to franchise standard operating procedures. Uniform administrative procedure (rather than adopting innovative practices across the franchisee outlets) contributes to consistency in quality service performance, which in turn, positively influences customer loyalty (Bitner, Booms, \& Tetreault, 1990; Kumar, 2002).

This study focuses on the domestic franchise business (Australian community pharmacies). Following a uniform operating procedure, the domestic pharmacy franchisees will be more useful to their customers by adapting to local requirements, as the customers will experience greater consistency and less variation in the service performance of the franchisee employees. This is likely to influence customer loyalty positively (Berry \& Parasuraman, 1991; Salanova, Agut \& Peiro, 2005). On the other hand, an innovative culture, in context of a domestic franchisee outlet, may have a negative effect on customers' perception of the franchisee due to possible variation in service performance across the franchisee outlets. In the context of the community pharmacy industry, the need for consistent employee service performance and for uniform guidelines for running the business, is indispensable (Beecroft 2007). Therefore, our next hypotheses regarding the drivers of customer loyalty at franchisor level is-

H2: Franchisors' innovative organizational culture negatively influence customer loyalty. 


\section{Support services}

Support services refer to the extent to which franchisors support the goals of franchisees, accommodate their needs, willingly participate in problem-solving and provide assistance as required by the franchisees (Grace et al., 2013). While franchisees manage the local operation of their franchises to realize profits and meet royalty contributions, franchisors provide ongoing training and operational and marketing support to ensure the effective dissemination of knowledge throughout the network (Paswan \& Wittmann, 2009). The franchisor is responsible for offering franchisees support in all kind of areas so that the franchisees can run their units (Gillis \& Combs, 2009; Roh \& Yoon, 2009). Franchisees often assess the franchisors' trustworthiness by assessing whether their franchisor has the willingness and the ability to provide them with operational support, such as regular supply of goods and services, actual timely delivery of the goods at the designated places, flexibility and care in delivery and support with ICT systems (Roh \& Yoon, 2009). Thus franchisee attitudes toward the franchisee-franchisor relationships are largely dependent on their ongoing evaluations of the nature and effectiveness of franchisor-provided support (Gassenheimer \& Ramsey, 1994). Franchisors may also contribute to the psychological climate of the franchisorfranchisee relationship through cohesive behaviour and consistent support, which positively influence franchisee performance (Strutton et al., 1993). Further, Grace et al. (2013) found that perceived support significantly influenced a franchisee's normative expectations and confirmation. This is likely to reflect on franchisee performance, thus affecting positive customer outcomes.

Past research (Evanschitzky et al., 2012) indicated that employees are more likely to positively influence customer satisfaction if they have the capabilities for addressing customer needs and if they demonstrate empathy. Sales employees who cater to the needs of customers positively influence attitudes such as satisfaction and loyalty (Evanschitzky et al., 2012). In addition, scholars researching the value-profit chain, argue that there is a potential flow of "emotional contagion" effect from store managers to store service employees and from store service employees to 
customers (Hennig-Thurau, Groth, Paul, \& Gremler, 2006; Netemeyer et al., 2010). Therefore, we argue that support services provided by the franchisor are likely to have an effect on the franchisee employee service performance, which eventually will positively influence customer attitudes such as loyalty. Hence our next hypotheses regarding the drivers of customer loyalty at franchisor level is -

H3: Franchisors' support services towards the franchisee positively influence customer loyalty.

\section{Autonomy}

Autonomy is the degree to which employees feel that they have independence, flexibility, discretion, and control in performing their jobs (Christen et al., 2006; Menguc et al., 2013). In the franchise context, autonomy refers to the extent of freedom that franchisees enjoy while running their outlets (Strutton et al., 1995). Autonomy enables the franchisees to have the control with respect to choosing specific operations and selecting a work pace (Dodd \& Ganster, 1996).

Existing research in the franchising context reports inconclusive findings with regard to the role of autonomy on franchisee success and performance. For example, Dant and Gundlach (1999) mention that the franchisee who is successful in terms of growth and profit may seek more autonomy from the franchisor; therefore, it is likely that successful franchisees enjoy a higher level of autonomy than less successful ones. In contrast, past research has pointed out that successful franchisees may attribute their success to their franchisors as a symbol of the franchisors' effective strategies in subjugating the marketplace competition (Anand \& Stern, 1985; Dant \& Gundlach, 1999). Thus franchisees may ascribe their market success to their franchisors' market initiatives and interventions, consider their relationship with the franchisors as a treasure, and desist from breaching them by seeking greater autonomy.

Pharmacy employees play a far more significant and distinct role compared to the employees in traditional retail contexts, as they usually play a dual role as a retail business employee as well as a health care provider (White \& Klinner, 2012). Pharmacy employees carry out their responsibilities 
in the demanding environment of the pharmacy store (Arndt, Arnold \& Landry, 2006). Evidence also indicates that pharmacy customers want their pharmacists to be more involved in advising about complementary medicines such as vitamins, and other supplements (Offord, 2013). In such situations, customers expect to receive a consistent and high quality service from pharmacy employees. Hence, adopting a centralized uniform business procedure is likely to be more useful for the pharmacy customers as opposed to an autonomous retail environmental. The autonomous environment may influence employee performance by deviating from the expected service level, which is likely to trigger a negative customer perception about the service performance of the employees.

Dodd and Ganster (1996) found that increased autonomy leads to increased job satisfaction if the franchise business consists of a high variety of tasks ${ }^{2}$ in terms of number of operations that the franchisee performs. However in the case of a low task variety, increased autonomy has a negligible and/or negative effect on job satisfaction, because autonomy in a low variety of tasks may create inconsistency in services delivered by the provider and may create confusion in the customer mind. Although the pharmacy employees perform different roles, their roles involve a low variety of tasks in terms of fundamental operations that pharmacy employees perform. Consequently we argue that the role of employee autonomy will have a negative influence on customer attitude, such as customer loyalty. This is because autonomy among employees encourages a tendency to avoid centralized decision-making (Jambulingam et al., 2005), which may not be suitable for the community pharmacy environment. Therefore, our next hypothesis regarding the drivers of customer loyalty at franchisor level is -

H4: Franchisee perceived autonomy negatively influences customer loyalty.

\footnotetext{
${ }^{2}$ Variety of task refers to the number of different operations a job entails and sets some upper limit on the amount of autonomy that can be exercised in a given job (Dodd and Ganster 1996). Consequently, high variety of task oriented franchisee connotes that the franchisee performs numerous operations as part of its business.
} 
The above hypothesized relationship is depicted in the following Figure 1.

\section{Figure 1: Conceptual Framework}

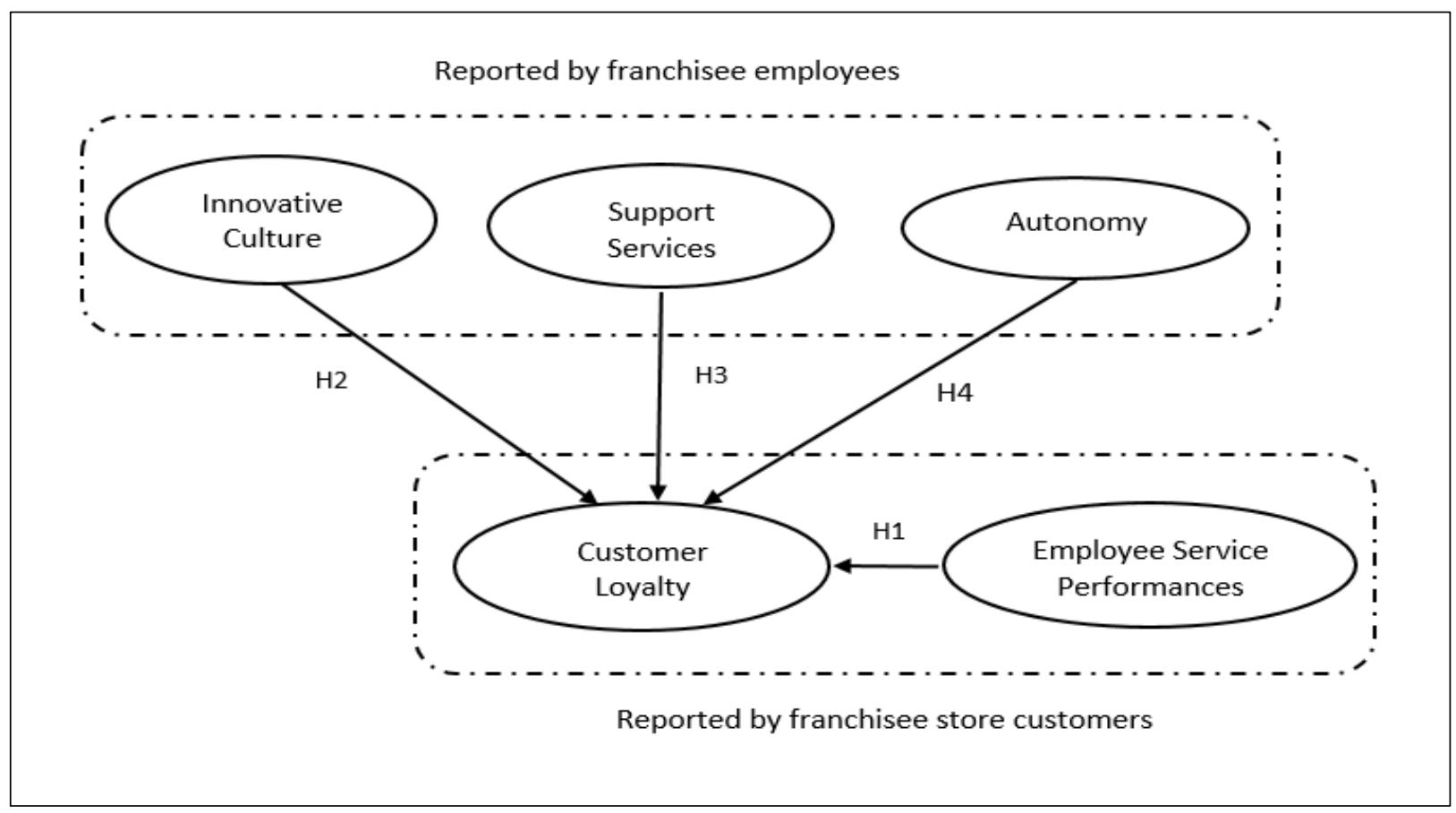

\section{Methodology}

As mentioned earlier, this study comprises two levels of analysis. Level 1 relates to community pharmacy customers, whereas level 2 relates to the employee of the community pharmacy store. The data for the study was collected from 25 stores of a large retail franchisee pharmacy chain in Australia. A sample of 40 retail franchise pharmacy stores were selected for data collection, using separate survey instruments for (i) store manager, and (ii) store customers from each store. The questionnaires (both for the customer and store level) were reviewed by a pharmacy expert for due adaptation of the scale items in a pharmacy context. The questionnaires were pre-tested among four employees and 10 customers from two pharmacy stores selected through network acquaintances. In case of the absence or unavailability of the store manager, the senior most store employee was requested to fill in the store level survey instrument. The customers of each of the 40 stores were selected at random over a two week period to collect customer level data. Finally, 38 employee and/or store manager level responses and 679 customer level responses from 25 stores were found 
to be useable, for inclusion in further analyses. A dyadic data set was created by matching customer data with employee data for each store.

At the customer level (level 1), we measured employee service performance as an independent variable, and customer loyalty as the dependent variable. Following Evanschitzky and Wunderlich (2006), we measured customer loyalty using the scale items adapted from the behavioural intention battery developed by Zeithaml, Berry, and Parasuraman (1996) and included three items: willingness to recommend, cross-buying intention, and repurchase intention. Guided by Salanova, Agut and Peiro (2005), employee performance was measured using scales that include empathy and job performance measures reflecting expected behaviours of the contact employees. Empathy was measured through SERVQUAL empathy scale (Parasuraman, Zeithaml \& Berry, 1988) and employee performance was measured by service provider's job performance scale (Price, Arnould \& Tierney, 1995). All items were measured using a seven point Likert scale ranging from 1 being strongly disagree and 7 being strongly agree. The descriptive statistics of the scale items and the psychometric properties of constructs are shown in Table 1.

At level 2, we considered different franchise management strategies such as innovative culture, support and autonomy, measured at employee level in the pharmacy stores. The measures for innovative culture and autonomy were adopted from Strutton et al. (1993). Support was measured by a five items scale adapted from King and Grace (2010) and Grace et al. (2013). All the items at store level were measured using a seven point Likert scale ranging from 1 being strongly disagree and 7 being strongly agree. The descriptive statistics of the scale items and the psychometric properties of constructs are shown in Table 1. 
Table 1 Descriptive statistics and psychometric properties of the constructs

\begin{tabular}{|c|c|c|c|c|}
\hline Levels & Constructs and Items & Loading & Mean & SD \\
\hline \multirow[t]{2}{*}{ Level 1: } & $\begin{array}{l}\text { Employee service performance }[\boldsymbol{\alpha}=\mathbf{0 . 8 9} ; \mathbf{C R}=\mathbf{0 . 9 6} ; \mathbf{A V E}= \\
\mathbf{0 . 8 3}] \\
\text { Employees understand specific needs of customers. } \\
\text { Employees are able to put themselves in the customers" place. } \\
\text { Employees are able to "tune in" to each specific customer. } \\
\text { Employees "surprise" customers with their excellent service. } \\
\text { Employees deliver an excellent service quality that is difficult to } \\
\text { find in other organizations. } \\
\text { Employees do more than usual for customers. }\end{array}$ & $\begin{array}{l}0.86 \\
0.86 \\
0.88 \\
0.82 \\
0.84 \\
0.87\end{array}$ & $\begin{array}{l}5.62 \\
5.74 \\
5.75 \\
5.85 \\
5.95 \\
6.47\end{array}$ & $\begin{array}{l}1.22 \\
1.21 \\
1.29 \\
1.15\end{array}$ \\
\hline & $\begin{array}{l}\text { Customer loyalty }[\boldsymbol{\alpha}=\mathbf{0 . 8 6} ; \mathbf{C R}=\mathbf{0 . 9 5} ; \mathbf{A V E}=\mathbf{0 . 8 7}] \\
\text { I would repurchase from this store. } \\
\text { I would intend to buy other products from this store. } \\
\text { I will return to this store in the future. }\end{array}$ & $\begin{array}{l}0.93 \\
0.85 \\
0.89 \\
\end{array}$ & $\begin{array}{l}6.55 \\
6.31 \\
6.58 \\
\end{array}$ & $\begin{array}{l}0.80 \\
1.06 \\
0.81\end{array}$ \\
\hline \multirow[t]{3}{*}{ Level 2: } & $\begin{array}{l}\text { Innovative culture }[\boldsymbol{\alpha}=\mathbf{0 . 8 6} ; \mathbf{C R}=\mathbf{0 . 9 4} ; \mathbf{A V E}=\mathbf{0 . 7 6}] \\
\text { XXXX (franchisor) encourages me to find new ways around old } \\
\text { problems. } \\
\text { XXXX (franchisor) encourages me to develop my own ideas. } \\
\text { XXXX (franchisor) encourages me to improve upon its } \\
\text { methods. } \\
\text { XXXX (franchisor) talks up new ways of doing things. } \\
\text { XXXX (franchisor) likes me to try new ways of doing things. }\end{array}$ & $\begin{array}{l}0.71 \\
\\
0.87 \\
0.86 \\
0.73 \\
0.83\end{array}$ & $\begin{array}{l}5.42 \\
\\
5.86 \\
5.86 \\
5.87 \\
5.94\end{array}$ & $\begin{array}{l}0.97 \\
\\
1.19 \\
1.14 \\
0.87 \\
0.84\end{array}$ \\
\hline & $\begin{array}{l}\text { Support services }[\boldsymbol{\alpha}=\mathbf{0 . 9 0} ; \mathbf{C R}=\mathbf{0 . 9 4} ; \mathbf{A V E}=\mathbf{0 . 7 8}] \\
\text { XXXX (franchisor) strongly considers my goals and values. } \\
\text { Help is readily available from my franchisor XXXX when I have } \\
\text { a problem. } \\
\text { XXXX (franchisor) understands and accommodates my } \\
\text { problems and needs. } \\
\text { XXXX (franchisor) supports me whenever possible. } \\
\text { XXXX (franchisor) helps me out no matter what it is. }\end{array}$ & $\begin{array}{l}0.65 \\
0.91 \\
0.93 \\
0.88 \\
0.72 \\
\end{array}$ & $\begin{array}{l}5.55 \\
5.78 \\
5.47 \\
5.81 \\
5.42 \\
\end{array}$ & $\begin{array}{l}1.22 \\
1.04 \\
1.08\end{array}$ \\
\hline & $\begin{array}{l}\text { Autonomy }[\boldsymbol{\alpha}=\mathbf{0 . 8 7} ; \mathbf{C R}=\mathbf{0 . 9 2} ; \mathbf{A V E}=\mathbf{0 . 7 2}] \\
\text { I organize the franchise as I see fit. } \\
\text { I set the work standards for me as a franchise. } \\
\text { I make most of the decisions that affect the way my franchise } \\
\text { performs. } \\
\text { I schedule my own work activities. } \\
\text { I determine my own operational routine. }\end{array}$ & $\begin{array}{l}0.64 \\
0.65 \\
0.80 \\
0.88 \\
0.87 \\
\end{array}$ & $\begin{array}{l}4.86 \\
6.00 \\
5.10 \\
\\
5.97 \\
5.65 \\
\end{array}$ & $\begin{array}{l}1.45 \\
0.80 \\
1.16 \\
\\
1.15 \\
1.23\end{array}$ \\
\hline
\end{tabular}

Note: $\alpha=$ Cronbach Alpha value; $C R=$ Composite Reliability; $A V E=$ Average variance extracted

\section{Data Analysis and Results}

Due to the dyadic nature of our data (nested at two different levels - customer level and employee level), we used hierarchical linear modelling (HLM) using HLM software in order to account for potential heterogeneity in the dependent variables because of different data levels (Evanschitzky et al., 2012; Netemeyer et al., 2010). HLM models individual and group level variations and recognizes partial interdependence of individuals within the same group, which is in our case, the 
pharmacy store. This approach allowed us to investigate individual and store level unit variance in the customer loyalty as the outcome variable. Specifically, HLM simultaneously estimates two models, the first modelling relationships within each individual customer level and the second modelling how these relationships within customers vary between pharmacy stores (Hofmann 1997; Martin and Hill 2012). In two-level hierarchical models as employed in this study, level 2 analyses use intercepts from Level 1 analyses as dependent variables. We depict the relevant equations of both the levels for the HLM below -

Level 1 model:

$$
\begin{aligned}
& \mathrm{CL}=\beta_{0}+\beta_{1}(\mathrm{ESP})+\mathrm{r} \\
& \text { Where }, \mathrm{CL}=\text { Customer loyalty } \\
& \mathrm{ESP}=\text { Employee service performance measured at customer level } \\
& \mathrm{r}=\text { error }
\end{aligned}
$$

Level 2 model:

$\beta_{0}=\delta_{00}+\delta_{01}($ FInnov $)+\delta_{02}($ FSupport $)+\delta_{03}($ FAuto $)+u$,

Where, FInnov= Franchisee innovative culture measured at franchisee level

FSupport $=$ Franchisee perceived support measure at franchisee level

FAuto $=$ Franchisee autonomy measured at franchisee level

$\mathrm{u}=$ error

For level 1 analysis (store level), customer loyalty of a pharmacy store was regressed by the predictor of employee service performance of that store. In the level 2 analysis, we used the intercept estimates obtained from level 1 as outcome variables and regressed on the store-level predictors that include the three franchise management strategies: innovative culture, support, and autonomy to assess the main effects of the store-level predictors. Therefore, we prepared two data files (Level 1: survey among the customers of different pharmacy stores; and, Level 2: survey among the employees of the respective pharmacy stores). These two data sources are "nested" (the customer data is nested within the employee data). The number of cases at the employee level is 25 , while the 
customer level cases were 679. We consider the sample size to be adequate to run the HLM analysis, as a sample size of 20 is suggested to be acceptable for multilevel studies (e.g. Hox, 1995; Evanschitzky et al., 2012)

The results of the HLM analysis presented in Table 2 show that at Level 1, employee service performance positively influence customer loyalty $\left(\beta_{1}=0.41 ; p<0.001\right)$. This result confirms H1. On the other hand, at Level 2 , innovative culture $\left(\delta_{01}=-0.12 ; \mathrm{p}=0.026\right)$ and autonomy $\left(\delta_{03}=-\right.$ $0.09 ; \mathrm{p}=0.007$ ) negatively influence the intercept of customer loyalty ( $\beta_{0}$ of Level 1$)$; and, support service $\left(\delta_{02}=0.16 ; \mathrm{p}<0.001\right)$ positively influence the intercept of customer loyalty. These lend support for $\mathrm{H} 2, \mathrm{H} 4$, and $\mathrm{H} 3$ respectively.

Table 2: HLM Regression Results

\begin{tabular}{c|c|c|c|c}
\hline Predictor & $\boldsymbol{\beta}$ & t-value & $\mathbf{p}$ - value & Decision \\
\hline $\begin{array}{c}\text { Level 1 (Dependent variable: customer loyalty) } \\
\text { Employee service performance }\end{array}$ & 0.41 & 12.57 & $<0.001$ & H1 Supported \\
\hline Level 2 (Dependent variable: $\beta_{0}$, intercept of & & & & \\
Level 1 equation) & & & & \\
Innovative culture & -0.12 & -2.39 & 0.025 & H2 Supported \\
Support services & 0.16 & 3.95 & $<0.001$ & H3 Supported \\
Autonomy & -0.09 & -3.08 & 0.007 & H4 Supported \\
\hline
\end{tabular}

\section{Discussion}

The key purpose of this research is to investigate the effects of franchise management strategies and employee service performance on customer loyalty from a multilevel view in the context of community pharmacy stores. At Level 1 i.e. at customer level, we find that employee perceived service performance has significant positive effect on customer loyalty. This is in line with the findings of the existing research such as Salanova et al. (2005), and Liao and Chuang (2004), who observed that employee performance and/or the quality of interaction between employees and customers influence customer loyalty. At Level 2 i.e. franchisor level, our findings suggest that out of the three franchisor management strategies, providing support services to franchisee employees 
positively influence customer loyalty. On the other hand, innovative culture and autonomy to store employees were found to have negative influence on customer loyalty. The positive influence of support services is reinforced by Grace et al. (2013) and Roh and Yoon (2009) who pointed out that franchisees evaluate the credibility of the franchisors based on the extent of support services (such as regular supply of goods and services, timely delivery at the designated places, flexibility and care in delivery, ICT support, etc.) they usually receive from the franchisors. The negative effects of innovative culture on customer loyalty as observed in our study could be explained by the fact that effective franchise systems traditionally have a set structure of managing daily store operations and resolving conflicts; and, the authority and power of deciding these set rules generally concentrated in the hands of the franchisor (Selz, 1992; Strutton et al., 1993). Employees of franchisee stores enjoy limited liberty to be innovative in franchise business. As mentioned before, franchisors often act as a central source of information, adopt one-way communication strategies with franchisees and minimize risks associated with non-conformity to franchise standard operating procedure and thus limits development of knowledge through innovative actions. This inhibits network innovation in the franchise system (King et al., 2013). This is also supported by Griffith et al. (2006) who found that retailers' entrepreneurial innovative tendency has a negative influence on their ability to convert resources into the dynamic capability of market responsiveness. The negative influence of autonomy on customer loyalty can be explained by the fact that unlike other channels that feature largely autonomous memberships, franchisees enjoy relatively less autonomy and are governed by a set of regulations given by the franchisor (Selz, 1992); and the franchisor has the power to suspend manifested franchise system conflict (Strutton et al, 1993). As argued by Dodd and Ganster (1996), employees in a situation of low autonomy have little control over how they work; and in such a situation, they usually become fairly consistent about the quality of their work. This results in customers receiving a standardized format of interactions and services across different franchisees instead of receiving differential and inconsistent services received from different franchisees due to innovative culture and autonomy. 
This paper contributes to the extant literature in three ways. First, it identifies and examines the effects of both customer level (employee service performance) and employee level drivers (franchise management strategies viz, innovative culture, support services and autonomy) on customer loyalty. The second contribution of this study relates to the data analysis. This research uses dyadic, multilevel data that has been infrequently used in research (Evanschitzky et al., 2012). With this data, we were able to clearly differentiate between customer-level (i.e. individual level) driver and employee level i.e. group-level drivers of customer loyalty. This allowed us to investigate the impact of the predictors at different levels on customer loyalty. Using this multilevel study design, we showed that a substantial mean-difference in customer loyalty exists between twenty five groups of store employees suggesting that their performance and corresponding effects on the customer loyalty vary systematically across groups. The third contribution of the paper emerges from our counter-intuitive findings that franchise management strategy such as innovative culture and autonomy negatively influence customer loyalty. In the franchise context, although franchisor and franchisee are two distinct business entities; customers usually do not think these two parties in isolation rather they simulate the impression of the franchisor on the franchisee. Hence customers of the franchisee stores prefer consistency in managing daily operations across different stores instead of distinct daily operations due to innovative culture and autonomy of the employees.

\section{Managerial implications}

We find that in the context of retail franchise pharmacies, customer loyalty enhances when customers hold positive perceptions about franchise employees' performance. This finding suggest that franchise store managers must invest in organizational resources and must pay attention to employees' motivation that increases collective engagement of employees and foster an excellent service climate with quality employee-customer interaction. Such service climate consequently increases customer appraisal of employee performance and, hence, customer loyalty. 
At the franchisor level, our findings suggest that the franchisor management strategy of providing adequate support services to franchisees positively influence customer loyalty. This finding demonstrates that it is critical for franchisee managers to provide adequate support services to franchisors to reinforce franchisee employee performance within the franchise system. Such reinforcement of franchisee employee performance will enhance customer loyalty. Thus, managers must ensure that adequate support services forms an essential component of franchisor management strategy. Such support could presumably play a broader role in the franchisee-franchisor relationship building process.

We find that franchisors' strategy of encouraging innovativeness among franchisee employees has negative influence on customer loyalty. This has important implications for managers of franchisees and franchisors. Managers must be cautious in offering freedom to franchisees to be innovative. While innovativeness in general has merits, it could also possibly turn franchisee employees risk averse, and act unconventional and thus potential non-conformity from the organization's policies and operating procedures. These could have detrimental effects in terms of inconsistencies in service provision, increased costs, etc. and reduce the effectiveness of franchise systems which traditionally rely on a set structure of managing daily store operations and conflict resolution, with the authority and power of deciding these set rules generally concentrated in the hands of the franchisor.

Our finding that franchisors' strategy of providing autonomy to store employees has negative influence on customer loyalty shows that managers must be careful in giving autonomy to employees in franchising context. This is particularly important in pharmacy context where customer-employee interactions are essentially on sensitive health related aspects, as such require greater control over employees, not less. When people are given the autonomy to make their own decisions, those decisions cease to be uniform. Thus, handing down of responsibility through 
autonomy could potentially increase the number of mistakes made (due to lack of adequate experience of employees) and put the reputation at risk.

\section{Limitations and future research directions}

Notwithstanding of above mentioned implications, this study is not out of limitations. In this study, customer loyalty has been measured using self-reported attitudinal measures of loyalty. Future research could consider testing the model by using actual purchase and referral data captured from pharmacies' transaction records. Also, given that this study has focused on pharmacy franchisee organizations, caution must be exercised in generalizing the findings of the study across other types of franchisees (e.g. fast food franchisees, supermarket franchisees, etc.) . Future research could focus on replicating this study to other types of franchisees (e.g. fast food franchisees, supermarket franchisees, etc.). In addition, our study considered only three management strategies (viz. innovativeness, autonomy and support). Future studies could consider studying the effect of other management strategies such as fairness and recognition (Strutton et al. 1993) on franchisee employee performance and customer loyalty. 


\section{Reference}

Anand, P., \& Stern, L.W. (1985). A socio-psychological explanation for why marketing channel members relinquish control. Journal of Marketing Research, 12(November), 365-376.

Annabel, B. (2006). Confronting the brutal facts. Australian Journal of Pharmacy, 87, 78-82.

Arndt, A., Arnold, T.J. \& Landry, T.D. (2006). The effects of polychronic-orientation upon retail employee satisfaction and turnover. Journal of Retailing, 82 (4), 319-330.

Ashforth, B. \& Humphrey, R. (1993). Emotional labour in service roles: The influence of identity. Academy of Management Review, 18 (1), 88-115.

Beecroft, G. (2007). Generic drug policy in Australia: a community pharmacy perspective. Australia and New Zealand Health Policy, 4(1), 1.

Berry, L. L. (1995). Relationship marketing of services - Growing interest, emerging perspectives. Journal of the Academy of marketing science, 23 (4), 236-245.

Berry, L. L., \& Parasuraman, A. (1991). Marketing services: Competing through quality. New York: Free Press.

Bitner, M.J. (1990). Evaluating service encounters: the effect of physical surroundings and employee responses. Journal of Marketing, 54 (2), 69-82.

Bitner, M. J., Booms, B. H., \& Tetreault, M. S. (1990). The service encounter: Diagnosing favourable and unfavourable incidents. The Journal of Marketing, 54 (January), 71-84.

Blut, M., Backhaus, C., Heussler, T., Woisetschläger, D. M., Evanschitzky, H., \& Ahlert, D. (2011). What to expect after the honeymoon: Testing a lifecycle theory of franchise relationships. Journal of Retailing, 87(3), 306-319.

Bordonaba-Juste, V., \& Polo-Redondo, Y. (2008). The effect of relationship marketing strategy on franchise channels: evidence from Spanish franchisees. Journal of Marketing Channels, 15 (1): $71-91$.

Bowen, D. E., \& Waldman, D. A. 1999. Customer-driven employee performance. In D. A. Ilgen \& E. D. Pulakos (Eds.), The changing nature of performance: 154-191. San Francisco: Jossey-Bass.

Brooks, J.M., Klepser, D.G., Urmie, J.M., Farris, K.B. \& Doucette, W.R. (2007), Effect of local competition on the willingness of community pharmacies to supply medication therapy management services. Journal of Health and Human Services Administration, 30 (1), 4-27.

Bush, J., Langley, C.A. \& Wilson, K.A. (2009). The corporatization of community pharmacy: Implications for service provision, the public health function, and pharmacy's claims to professional status in the United Kingdom. Research in Social and Administrative Pharmacy, 5 (4), 305-318.

Campbell, J.P., McCloy, R.A., Oppler, S.H. \& Sager, C.E. (1993). A theory of performance”, in Schmitt, N. and Borman, W.C. (Eds), Personnel Selection in Organizations, Jossey-Bass, San Francisco, CA, 35-70. 
Castrogiovanni, G.J., Combs, J.G. \& Justis, R.T. (2006). Shifting imperatives: an integrative view of resource scarcity and agency reasons for franchising. Entrepreneurship Theory and Practice, 30 (1), 23-40.

Chiou, J.S., Hsieh, C.H., \& Yang, C. H. (2004). The Effect of Franchisor's Communication, Service Assistance, and Competitive Advantage on Franchisees' Intentions to Remain in the Franchise System. Journal of Small Business Management, 42(1), 19-36.

Chung, J.E., Sternquist, B. \& Chen, Z. (2006). Retailer-buyer supplier relationships: the Japanese difference. Journal of Retailing, 82 (October), 349-55.

Combs JG, Ketchen DJ, Shook CL, et al. (2011) Antecedents and consequences of franchising: Past accomplishments and future challenges. Journal of Management 37(1): 99-126.

Christen, M., Iyer, G., \& Soberman, D. (2006). Job satisfaction, job performance, and effort: A reexamination using agency theory. Journal of Marketing, 70(1), 137-150.

Croonen, E. P., \& Brand, M. J. (2015). Antecedents of franchisee responses to franchisor-initiated strategic change. International Small Business Journal, 33(3), 254-276.

Dada, O., Watson, A. \& Kirby, D.A. (2012). Toward a model of franchisee entrepreneurship. International Small Business Journal, 30(5): 559-583.

Damanpour, F. (1991). Organizational innovation: A meta-analysis of effects of determinants and moderators. Academy of management journal, 34(3), 555-590.

Damanpour, F., \& Evan, W. M. (1984). Organizational innovation and performance: the problem of" organizational lag". Administrative science quarterly, 392-409.

Dant, R.P., Grünhagen, M. \& Windsperger, J. (2011). Franchising research frontiers for the twenty-first century. Journal of Retailing, 87(3): 253-268.

Dant, R. P., \& Kaufmann, P. J. (2003). Structural and strategic dynamics in franchising. Journal of Retailing, 79(2), 63-75.

Dant, R. P., \& Gundlach, G. T. (1999). The challenge of autonomy and dependence in franchised channels of distribution. Journal of Business Venturing, 14(1), 35-67.

Dant, R. P., Weaven, S. K., \& Baker, B. L. (2013). Influence of personality traits on perceived relationship quality within a franchisee-franchisor context. European Journal of Marketing, $47(1 / 2), 279-302$.

Dant, R. P., \& Nasr, N. I. (1998). Control techniques and upward flow of information in franchising in distant markets: conceptualization and preliminary evidence. Journal of Business Venturing, 13(1), 3-28.

Davies, MAP, Lassar, W., Manolis, C., et al. (2011). A model of trust and compliance in franchise relationships. Journal of Business Venturing, 26(3), 321-340.

DiPietro, R.B., Severt, D., Welsh, D.H.B., \& Raven, P.V. (2008). Franchisee leadership traits vs. manager leadership traits: An exploratory study comparing hope, leadership, commitment, 
and service quality delivery. International Entrepreneurship and Management Journal, $4(1), 63-78$.

Doherty, A. \& Alexander, N. (2004). Relationship development in international retail franchising. European Journal of Marketing, 38 (9/10), 1215-35.

Dodd, N. G., \& Ganster, D. C. (1996). The interactive effects of variety, autonomy, and feedback on attitudes and performance. Journal of Organizational Behavior, 17(4), 329-347.

Eisenhardt, K., \& Schoonhoven. K. (1996). Resource-based view of strategic alliance formation: Strategic and social effects in entrepreneurial firms. Organization Science, 7, 136-151.

Etgar, M. (1979). Sources and Types of Inter-channel Conflict.' Journal of Retailing, 55 (spring), 61-78.

Evanschitzky, H., Groening, C., Mittal, V., \& Wunderlich, M. (2011). How employer and Employee satisfaction affect customer satisfaction: An application to franchise services. Journal of Service Research, 14 (2), 136 - 148.

Evanschitzky, H., Sharma, A., \& Prykop, C. (2012). The role of the sales employee in securing customer satisfaction. European Journal of Marketing, 46(3/4), 489-508.

Evanschitzky, H., \& Wunderlich, M. (2006). An examination of moderator effects in the fourstage loyalty model. Journal of Service Research, 8(4), 330-345.

Gallini, N., \& Lutz, N. (1992). Dual distribution and royalty fees in franchising. Journal of Law, Economics and Organization, 8, 471-501.

Gassenheimer, J. B., Baucus, D. B. \& Baucus, M. S. (1996). Cooperative Arrangements among Entrepreneurs: An Analysis of Opportunism and Communication in Franchise Structures. Journal of Business Research, 36 (1), 67-79.

Gassenheimer, J. B. \& Ramsey, R. (1994). The Impact of Dependence on Dealer Satisfaction: A Comparison of Reseller - Supplier Relationships, Journal of Retailing, 70 (3), 253-66.

Gillis, W. E., \& Combs, J. G. (2009). Franchisor strategy and firm performance: Making the most of strategic resource investments. Business Horizons, 52(6), 553-561.

Grace, D., Weaven, S., Frazer, L., \& Giddings, J. (2013). Examining the role of franchisee normative expectations in relationship evaluation. Journal of Retailing, 89(2), 219-230.

Griffith, D. A., Noble, S. M., \& Chen, Q. (2006). The performance implications of entrepreneurial proclivity: A dynamic capabilities approach. Journal of Retailing, 82(1), 51-62.

Grönroos, C. (1990). Marketing redefined. Management Decision, 28 (8), 5-12.

Gwinner, K.P., Gremler, D.D. \& Bitner, M.J. (1998). Relational benefits in service industries: the customers' perspective, Journal of the Academy of Marketing Science, 26(2), 101-114.

Hamilton, J. (2009). Building a targeted pharmacy customer engagement approach. International Journal of Pharmaceutical and Healthcare Marketing, 3 (4), 381-396. 
Han, J. K., Kim, N., \& Srivastava, R. K. (1998). Market orientation and organizational performance: Is innovation a missing link? The Journal of marketing, 62 (October), 30-45.

Hennig-Thurau, T., Groth, M., Paul, M. \& Gremler, D.D. (2006). Are all smiles created equal? How emotional contagion and emotional labour affect service relationships. Journal of Marketing, 70 (July), 58-83.

Hochschild, A. (1983), The Managed Heart, University of California Press, Berkeley, CA.

Hofmann, D. A. (1997). An Overview of the Logic and Rationale of Hierarchical Linear Models. Journal of Management, 23 (6), 723-44.

Hox, J. (1995), Applied Multilevel Analysis, TT- Publikaties, Amsterdam.

Jacobs, S., Ashcroft, D. \& Hassell, K. (2011). Culture in community pharmacy organizations: What can we glean from the literature?, Journal of Health Organization and Management, 24 (4), 420-454.

Jensen, R. J., \& Szulanski, G. (2007). Template use and the effectiveness of knowledge transfer. Management Science, 53 (11), 1716-1730.

Jambulingam, T., Kathuria, R., \& Doucette, W. R. (2005). Entrepreneurial orientation as a basis for classification within a service industry: The case of retail pharmacy industry. Journal of operations management, 23(1), 23-42.

Kaufmann, P. J., \& Eroglu, S. (1999). Standardization and adaptation in business format franchising. Journal of Business Venturing, 14(1), 69-85.

King, C. \& Grace, D. (2010). Building and Measuring Employee Based Brand Equity. European Journal of Marketing, 44 (7/8), 938-71.

Kozlowski, S. W. J., \& Klein, K. J. (2000). A multilevel approach to theory and research in organizations: Contextual, temporal, and emergent processes. In K. J. Klein \& S. W. J. Kozlowski (Eds.), Multilevel theory, research, and methods in organizations: 3 - 90. San Francisco: Jossey-Bass

Kumar, P. (2002). The impact of performance, cost, and competitive considerations, on the relationship between satisfaction and repurchase intent in business markets. Journal of Service Research, 5, 55 - 69.

Lafontaine, F., \& Kaufmann, P. J. (1994). The evolution of ownership patterns in franchise systems. Journal of Retailing, 70 (2), 97-113.

Larson, J. (1998). Patient satisfaction with delivery of products and information by an ambulatory care pharmacy. American Journal of Health-System Pharmacy, 55 (10), 1025-1029.

Liao, H. \& Chuang, A. (2004). A multilevel investigation of factors influencing employee service performance and customer outcomes. Academy of Management Journal, 47 (1), 41-58.

Lundy, O. \& Cowling, A. (1996). Strategic Human Resource Management, Routledge, London. 
Martin, K. D., \& Hill, R. P. (2012). Life satisfaction, self-determination, and consumption adequacy at the bottom of the pyramid. Journal of Consumer Research, 38(6), 1155-1168.

McMillan, S.S., Sav, A., Kelly, F., King, M.A., Whitty, J.A. \& Wheeler, A.J. (2014). How to attract them and keep them: the pharmacy attributes that matter to Australian residents with chronic conditions. International Journal of Pharmacy Practice, 22 (4), 238-245.

Menguc, B., Auh, S., Fisher, M., \& Haddad, A. (2013). To be engaged or not to be engaged: The antecedents and consequences of service employee engagement. Journal of business research, 66(11), 2163-2170.

Netemeyer, R. G., Maxham III, J. G., \& Lichtenstein, D. R. (2010). Store manager performance and satisfaction: effects on store employee performance and satisfaction, store customer satisfaction, and store customer spending growth. Journal of Applied Psychology, 95(3), 530 .

Norton, S. (1988). An empirical look at franchising as an organisational form. Journal of Business, 61 (2), 197-218.

Offord, L. (2013). Feature - vitamins and supplements: complementing patient support with knowledge. The Australian Journal of Pharmacy, 94 (1113), 40-42.

Oliver, R.L. (1999). Whence consumer loyalty. Journal of Marketing, 63 (4), 33-44.

Menon, A., \& Varadarajan, P. R. (1992). A model of marketing knowledge use within firms. Journal of Marketing, 56 (4), 53-71.

Palmatier, R. W., Dant, R.P., Grewal, D. \& Evans, K. R. (2006). Factors Influencing the Effectiveness of Relationship Marketing: A Meta-Analysis. Journal of Marketing, 70 (4), $136-53$.

Parasuraman, A., Zeithaml, V. A., \& Berry, L. L. (1988). Servqual. Journal of retailing, 64(1), 1240.

Paswan, A. K. \& Wittmann, C. M. (2009). Knowledge Management and Franchise Systems. Industrial Marketing Management, 38 (2), 173-80.

Powell, W., Koput, K. \& Smith-Doerr, L. (1996). Inter-organizational collaboration and the locus of innovation: Networks of learning in biotechnology. Administrative Science Quarterly, 46, $116-145$.

Price, L. L., Arnould, E. J., \& Tierney, P. (1995). Going to extremes: Managing service encounters and assessing provider performance. Journal of Marketing, 83-97.

Rabbanee, F. K., Burford, O., \& Ramaseshan, B. (2015). Does employee performance affect customer loyalty in pharmacy services?. Journal of Service Theory and Practice, 25(6), 725743.

Ramaseshan, B., Ishak, A., \& Rabbanee, F. K. (2013). The role of marketing managers' commitment and involvement in marketing strategy implementation. Journal of Strategic Marketing, 21(6), 465-483. 
Roh, E. Y., \& Yoon, J. H. (2009). Franchisor's ongoing support and franchisee's satisfaction: a case of ice cream franchising in Korea. International Journal of Contemporary Hospitality Management, 21(1), 85-99.

Salanova, M., Agut, S., \& Peiró, J. M. (2005). Linking organizational resources and work engagement to employee performance and customer loyalty: the mediation of service climate. Journal of applied Psychology, 90 (6), 1217.

Saraogi, A. (2009). Exploring franchisor franchisee relationship: Building a predictive model of franchisee performance. Vision: The Journal of Business Perspective, 13(1), 31-58.

Selz, Michael. (1992). Many Ex-Executives Tum to Franchising, Often Find Frustration. Wall Street Journal 150 (October 14): Al -A4.

Shane, S., Shankar, V., \& Aravindakshan, A. (2006). The effects of new franchisor partnering strategies on franchise system size. Management Science, 52(5), 773-787.

Shuai, G.E., et al. (2012). Provision and usage of medical services by community pharmacy: a comparative study of New York, Macao and Zhuhai (China). Canadian Social Science, 8 (6), 11-17.

Singleton, J.A. \& Nissen, L.M. (2014). Future-proofing the pharmacy profession in a hypercompetitive market. Research in Social and Administrative Pharmacy, 10 (2), 458468.

Spinelly, S. \& Sue, B. (1996). Toward a Theory of Conflict in the Franchise System. Journal of Business Venturing, 11 (5), 329-42.

Strutton, D., Pelton, L. E., \& Lumpkin, R. (1993). The Influence of Psychological Climate on Conflict Resolution Strategies in Franchising Relationships. Journal of the Academy of Marketing Science, 21 (Summer), 207-215.

Strutton, D., Pelton, L. E., \& Lumpkin, J. R. (1995). Psychological climate in franchising system channels and franchisor-franchisee solidarity. Journal of Business Research, 34(2), 81-91.

Szulanski, G., \& Jensen, R. J. (2008). Growing through copying: The negative consequences of innovation on franchise network growth. Research Policy, 37(10), 1732-1741.

Uzkurt, C., Kumar, R., Semih Kimzan, H., \& Eminoglu, G. (2013). Role of innovation in the relationship between organizational culture and firm performance: A study of the banking sector in Turkey. European Journal of innovation management, 16(1), 92-117.

Weaven, S., Grace, D., Dant, R., \& R. Brown, J. (2014). Value creation through knowledge management in franchising: a multi-level conceptual framework. Journal of Services Marketing, 28(2), 97-104.

White, D. W. (2010). The impact of marketing strategy creation style on the formation of a climate of trust in a retail franchise setting. European Journal of Marketing, 44(1/2), 162179.

White, L. and Klinner, C. (2012). Service quality in community pharmacy: an exploration of determinants. Research in Social and Administrative Pharmacy, 8 (2), 122-132. 
$\mathrm{Xu}, \mathrm{T}$. (2002). Choice of and overall satisfaction with pharmacies among a community-dwelling elderly population. Medical Care, 40 (12), 1283-1293.

Zeithaml, V. A., Berry, L. L., \& Parasuraman, A. (1996). The behavioural consequences of service quality. Journal of Marketing, 31-46. 